\title{
Analyzing impact of changing fuel-mix composition of Thailand power generation
}

\author{
Chanaipong Srichai ${ }^{1}$, Pongsun Bunditsakulchai ${ }^{2}$, and Thitisak Boonpramote ${ }^{3}$ \\ ${ }^{1}$ Chulalongkorn University, Graduate School, Bangkok, Thailand \\ ${ }^{2}$ Chulalongkorn University, Faculty of Engineering, Bangkok, Thailand \\ ${ }^{3}$ Chulalongkorn University, Faculty of Engineering, Bangkok, Thailand
}

\begin{abstract}
The energy industry is considered one of the important sectors for national economic development - especially the electricity generation industry then Thailand has developed a power development plan as the nation roadmap to ensure power security and reliability of the electricity system. In this study, we focus on the electricity generation industry and examine the impacts resulting from the changing composition of power generation type compare between Thailand's Power Development Plan year 2015 and the year 2018. The scenario case 1 assuming that the electricity generation is generated from $37 \%$ of Natural Gas, $23 \%$ of Coal, and $50 \%$ other. When the changing fuel proportion by increasing Gas-fired power plant to $53 \%$ and decrease Coal-fired power plant and other to $12 \%, 35 \%$ accordingly in scenario case 2 . As a result, Power Development Plan year 2018 is increase more the total output of the Thai economy than the Plan year 2015 cause to significantly benefit of the economy.
\end{abstract}

\section{Background}

Thailand Power Development Plan or PDP, which is a master plan for the national electricity supply in the long term for 15-20 years in order to build a stable and sufficient electricity demand to support the economic and social development of the country, including the quality of life of the people. However, the power development plan 2015 of Thailand was focused on the management risk by balancing diversification of fuel used and sufficient electricity supply for the whole country electricity demand but not considered on the conditions of the electricity distribution system or the management of fuel sources with details separated by region, including the determination of power plants for security in each area. After implemented it for a while, electricity consumption has changed from the prediction of electricity demand. Also, the government of Thailand response by the Ministry of energy has to review and improve the plan to be in line with the current situation. The Ministry took the regional electricity supply to be the criteria but remove the balancing of diversification of fuel used. Therefore leading to the question of research that what is the impact on the economy from the changing composition of power generation following the power development plan 2018.

\footnotetext{
* Corresponding author: sc.chnai@gmail.com
} 


\subsection{Power development plan $2015^{[1]}$}

The power development plan 2015 use for developing and implement as nation roadmap from $2014-2036$. The forecast electricity demand has assumed by

- Average GDP growth will be 3.94\% annually

- $\quad$ Population growth will average $0.03 \%$ annually

- $\quad$ Energy savings forecasted in the EEDP will total 89,672 GWh

- Renewables will supply 19,634.4 MW,

- New power demands will grow 2.67 percent annually

- $\quad$ in 2036 Thailand's peak electricity demand will be 49,655 MW

- Total electricity demand will be 326,119 GWh.

At the end of the plan, the power plant's installed capacity shall separate from fuelling type shown in Table 1.

Table 1. Power plant's installed capacity in 2036.

\begin{tabular}{|c|c|}
\hline Fuel Type & Percentage \\
\hline Natural Gas & $37 \%$ \\
\hline Coal & $23 \%$ \\
\hline Import & $15 \%$ \\
\hline Renewable & $20 \%$ \\
\hline Nuclear & $5 \%$ \\
\hline Diesel/Fuel & $0 \%$ \\
\hline
\end{tabular}

\subsection{Power development plan $2018^{[2]}$}

In 2018, Thailand lead by Ministry of Energy together with Electricity Generating Authority of Thailand prepared the power development plan 2018[2] use for $2018-2037$. The plan changing fuel composition by increase electricity generating from Gas power plant and decrease Coal and import power plant shown in Table 2.

Table 2. Power plant's installed capacity in 2037.

\begin{tabular}{|c|c|}
\hline Fuel Type & Percentage \\
\hline Natural Gas & $53 \%$ \\
\hline Coal & $12 \%$ \\
\hline Import & $9 \%$ \\
\hline Renewable & $20 \%$ \\
\hline EE & $6 \%$ \\
\hline Diesel/Fuel & $0 \%$ \\
\hline
\end{tabular}

\section{Research methodology ${ }^{[3]}$}

\section{Input-output analysis}

Input-output analysis is the tool that show the relationship between production and primary factors, intersectoral flows, and final demand and transfer, which links various production sectors in the entire economy systematically, as shown in formula 1

$$
\mathrm{x}_{\mathrm{i}}=z_{i 1}+\cdots+z_{i j}+\cdots+z_{i n}+f_{i}=\sum_{j=1}^{n} z_{i j}+f_{i}
$$


Where, Zij represents transactions from sector $i=1,2, \ldots, n$ use as intermediate input of sector $j=1,2, \ldots, n$ when $n$ is the total of economic sectors

$f_{i}$ represents total final demand of sector $i$

$x_{i}$ represents total output of sector $i$

Or describe in linear algebra as below

$$
\mathbf{x}=\mathbf{Z i}+\mathbf{f}
$$

Where, $i$ represent column vector of 1 's of appropriate $\mathrm{n}$ dimension

If the assumption of the Input-Output model is as follows

- The raw materials used in the same production sectors are assumed to be the same and assumed to be not similar in different production sectors

- In a short period (not more than 3-5 years), the price of used raw material in each production sector is fixed as assumed a used constant proportion, with have no further economy of scale, non-substitutability and non-unemployment. The employment shall depend on increasing of demand

Then formula (2) can describes in from of "Leontief Inverse" as below

$$
\mathbf{x}=(\mathbf{I}-\mathbf{A})^{-1} \mathbf{f}=\mathbf{L} \mathbf{f}
$$

formula (3) is used to initiate the study in order evaluate the outcome on economy to by changing the final demand or Production function related to increasing of the electricity generation's composition on the base year. by given $\mathbf{f}_{\text {PDP2015 }}$ represent the increasing of installed capacity with composition of fuel following the power development plan 2015 and $\mathbf{f}_{\text {PDP2018 }}$ represent the increasing of installed capacity with composition of fuel following the power development plan 2018. Then formula (3) can describe in from of formula (4) and (5) as follows

$$
\begin{aligned}
& \Delta \mathbf{x}_{\text {PDP2015 }}=\mathbf{L} \Delta \mathbf{f}_{\mathrm{PDP} 2015} \\
& \Delta \mathbf{x}_{P D P 2018}=\mathbf{L} \Delta \mathbf{f}_{\mathrm{PDP} 2018}
\end{aligned}
$$

The comparison of the monetary impact on economy is expected as

$$
\% \mathbf{x}=\Delta \mathbf{x}_{P D P 2018} / \Delta \mathbf{x}_{P D P 2015}
$$

For the use of Multiplier, it is a coefficient which describes the effect on the economy's changing by external factors or Exogenous changes. It usually uses for analysing the several estimations of the effects of exogenous changes such as

1. the total outputs of each production sector.

2. the household's income in each production sector.

3 . the increasing of employment in each production sector.

4. Value-added of each production sector e.g. indirect tax, profits.

The Income Multiplier is commonly used to analyse the impact of final demand by show the increase in income from employment that result from a change of one unit of income from employment in each industry, which is calculated by multiplying total output in each sector by the income coefficient of the sector as

$$
\mathbf{m}(\boldsymbol{h})=\varepsilon^{\prime} \mathbf{L}
$$




\section{Result and discussion}

\subsection{Database}

The study uses the data from the Global Trade Analysis Project Power data base or GTAPPower which is the electricity-detailed extension of the GTAP Data Base and change into the Input-output table for the analysis. The GTAP data base take the resource from Thailand's Input-output table 2011 that generated from office of the National Economic and social Development Council and separate electricity sector into: transmission \& distribution, nuclear, coal, gas (base and peak load), oil (base and peak load), hydroelectric (base and peak load), wind, solar, and other power technologies as shown all the sector in this study in Table 3.

\subsection{Scenarios}

According to data base on 2011 and Thailand's power development plan, the Thailand's power consumption from year 2011 to year 2036 shall increase from 164,089.92 ${ }^{[4]} \mathrm{GWh}$ to $326,120.00^{[1]} \mathrm{GWh}$. the study set up the scenarios in 2 scenarios to compare the economic impacts of energy policy between 2 power development plans

- The first scenario is referred to power development plan year 2015 which balance the power generation composition by use Natural Gas, Coal, Renewable, Hydro, Nuclear and other as 33\%,21\%,16\%,16\%, 4\% and 9\% accordingly at year 2036

- The second scenario is referred to power development plan year 2018 which the power generation composition generates by Natural Gas, Coal, Renewable, Hydro, Nuclear and other are $51 \%, 12 \%, 17 \%, 12 \%, 0 \%$ and $9 \%$ accordingly at year 2036 As shows in Table 4. 
Table 3. GTAP data sectors.

\begin{tabular}{|c|c|}
\hline aff & Agriculture, Forestry and Fishing \\
\hline coa & Coal \\
\hline oil & Oil \\
\hline gas & Gas \\
\hline own & Other minings \\
\hline fod & Food processing products \\
\hline p_c & Petroleum, coal products \\
\hline crp & Chemical, rubber, plastic products \\
\hline $\mathrm{nmm}$ & Ferrous, non-ferrous and metal products \\
\hline prm & Primary industries (textile, leather, wood, paper) \\
\hline teq & Motor vehicles and transport equipment \\
\hline ele & Electronic equipment \\
\hline ome & Machinery and equipment \\
\hline $\mathrm{xmf}$ & Other manufactures \\
\hline tnd & Transmission \& distribution \\
\hline nuc & Nuclear power electricity \\
\hline $\mathrm{cnl}$ & Coal power electricity \\
\hline gss & Gas power electricity \\
\hline wnd & Wind power electricity \\
\hline hyd & Hydroelectric \\
\hline oll & Oil power electricity \\
\hline slr & Solar power electricity \\
\hline xel & Other electricity \\
\hline gdt & Gas manufacture, distribution \\
\hline cns & Construction \\
\hline $\operatorname{trd}$ & Trade \\
\hline xtp & Transportation \\
\hline $\mathrm{cmn}$ & Communication \\
\hline fsi & Financial services, insurance and business services \\
\hline xsv & Other services \\
\hline
\end{tabular}


Table 4. Scenarios.

\begin{tabular}{|c|c|c|c|c|}
\hline \multirow{2}{*}{$\begin{array}{c}\text { Electricity } \\
\text { Sectors }\end{array}$} & $\begin{array}{c}|c| \\
\text { Seneration } \\
(\mathrm{GWh})\end{array}$ & Percentage & $\begin{array}{c}\text { Generation } \\
(\mathrm{GWh})\end{array}$ & Percentage \\
\cline { 2 - 5 } & $30,277.62$ & $9.3 \%$ & $32,212.35$ & $9.3 \%$ \\
\hline tnd & $14,599.80$ & $4.5 \%$ & 0.00 & $0.0 \%$ \\
\hline nuc & $66,911.90$ & $20.5 \%$ & $41,858.01$ & $12.1 \%$ \\
\hline cnl & $109,048.97$ & $33.4 \%$ & $177,911.34$ & $51.3 \%$ \\
\hline gss & $9,056.65$ & $2.8 \%$ & $9,056.65$ & $2.6 \%$ \\
\hline wnd & $52,165.49$ & $16.0 \%$ & $34,758.04$ & $10.0 \%$ \\
\hline hyd & 46.89 & $0.0 \%$ & 100.42 & $0.0 \%$ \\
\hline oll & $18,101.22$ & $5.6 \%$ & $18,101.22$ & $5.2 \%$ \\
\hline slr & $25,911.44$ & $7.9 \%$ & $32,960.97$ & $9.5 \%$ \\
\hline xel & & & & \\
\hline
\end{tabular}

\subsection{Result and conclusion}

The considering the input-output table with the linkage of each electricity sector by Forward linkage that describes the relationship between one production unit is used as inputs for other production units. It can be seen that the production of electricity from Gas-fired power plants will affect other production units up to 1.59 , which is higher than coal-fired power plants that are 1.12 as shown the details in Table 5.

Table 5. The result of sector's forward linkage.

\begin{tabular}{|c|c|}
\hline & forward linkage \\
\hline tnd & 1.20 \\
\hline nuc & 1.00 \\
\hline cnl & 1.12 \\
\hline gss & 1.59 \\
\hline wnd & 1.00 \\
\hline hyd & 1.01 \\
\hline oll & 1.02 \\
\hline slr & 1.00 \\
\hline xel & 1.01 \\
\hline tnd & 1.20 \\
\hline
\end{tabular}

However, the considering of backward linkage that describes the relationship between other production units is used as inputs of the considered sector. It can be seen that both Gas-fired and Coal-fired are 2.46 and 2.55 accordingly. 
Table 6. The result of sector's backward linkage.

\begin{tabular}{|c|c|}
\hline & forward linkage \\
\hline tnd & 1.00 \\
\hline nuc & 2.46 \\
\hline cnl & 2.55 \\
\hline gss & 1.16 \\
\hline wnd & 1.16 \\
\hline hyd & 3.08 \\
\hline oll & 1.12 \\
\hline slr & 2.18 \\
\hline xel & 1.00 \\
\hline tnd & 2.46 \\
\hline
\end{tabular}

As shown in Table 7, The analysis with the power generation composition as in scenario I and scenario II started by analyzing the result of considering the increase of value-added of the economy of Scenarios II. It is found that there is a slight difference between the scenarios. When considering additional in the total income by income multiplier, the increase of scenario II above scenario I up to $11.91 \%$ show that the use of a gas fuel generation higher than coal directly more affects the total income of the economy. However, when considering the tax that the government will receive, compare both scenarios reduce more than $38.13 \%$ which offset with the total income also the total value-added is slightly different. And the comparison of the increasing total output between both scenarios which is the essential variable that shows the impact of the entire Thailand economic system. It is found that the total output of scenario II has a higher value than 7.88 percentage above the scenario II.

Table 7. The result comparison.

\begin{tabular}{|l|c|c|c|}
\hline & Scenario I & Scenario II & \% Comparison \\
\hline Delta Value-added multiplier & $84,328.62$ & $84,304.14$ & $-0.03 \%$ \\
\hline Delta income multiplier & $16,749.42$ & $18,743.49$ & $+11.91 \%$ \\
\hline Delta Tax multiplier & $7,765.29$ & $4,804.65$ & $-38.13 \%$ \\
\hline Delta Total Output & $173,608.39$ & $187,289.40$ & $+7.88 \%$ \\
\hline
\end{tabular}

Form the analysis results mentioned above, it can conclude that increasing the composition of Gas fuel, according to the power development plan 2018, will significantly benefit the economy. The relevant government agencies can use the results of this study to be the information and tools to determine the suitable proportion to achieve the highest economic benefits that the study shows the increasing of the composition of gas-fired power plants will benefit the overall economy better than the coal-fired power plants. However, the government has to consider the breakeven point of losing revenue from taxation as well.

\section{References}

1. Ministry of Energy, Thailand Power Development Plan 2015-2036 (PDP2015), (2015)

2. Ministry of Energy, Thailand Power Development Plan 2018-2037 (PDP2018), (2019)

3. N. Thanarat, B. Pongsan, A Thesis in Economic and Energy Impacts Resulting from the Transportation Model Shift of Cement Industry, Bangkok, Thailand (2017)

4. The Energy Policy and Planning office, Energy Statics of Thailand 2012, (2012) 